Електронне наукове фахове видання "Ефективна економіка" включено до переліку наукових фахових видань України з питань економіки (Категорія «Б», Наказ Міністерства освіти і науки України від 11.07.2019 № 975) www. economy.nayka.com.ua | № 2, 2021 | 25.02.2021 p.

DOI: $10.32702 / 2307-2105-2021.2 .2$

УДК 336.7: 001.891.5

N. Trusova

Doctor of Economic Sciences, Professor, Professor of the Department of Finance, Banking and Insurance, Dmytro Motornyi Tavria State Agrotechnological University

ORCID ID: 0000-0001-9773-4534

I. Chkan

PhD in Economics, Associate Professor, Associate Professor of the Department of Finance, Banking and Insurance, Dmytro Motornyi Tavria State Agrotechnological University ORCID ID: 0000-0003-3764-8380

\title{
MINIMIZATION OF RISKS OF PAYMENT SYSTEMS OF BANKING INSTITUTIONS
}

\begin{abstract}
Н. В. Трусова,
д. е. н., професор, професор кафедри фінансів, банківської справи та страхування, Таврійський державний агротехнологічний університет імені Дмитра Моторного I. О. Чкан,

к. е. н., дочент, дочент кафедри фінансів, банківської справи та страхування, Таврійський державний агротехнологічний університет імені Дмитра Моторного
\end{abstract}

\section{МІНІМІЗАЦІЯ РИЗИКІВ ПЛАТІЖНИХ СИСТЕМ БАНКІВСЬКИХ УСТАНОВ}

The article presents a direction of minimizing the risks of payment systems of banking institutions in the context of the development of digitalization of the economy and the impact of environmental factors on the functioning of payment market participants. In order to identify the characteristic features of threats to corporate banking operations under the influence of environmental factors, the category "risk of payment systems of banking institutions" is proposed. It is substantiated that unpredictable deviations from the expected results of using financial instruments in interbank money transfer systems, which provide money circulation through active-passive operations, reduce the volume of operating activities of banking institutions, their settlement processes for payments and transfers of participants and users of payment systems. It is proved that the division of risks into specific and individual allows to assess the state of the payment system in two directions: internal - on the technology of settlement operations, which depend entirely on the activities of payment system participants, and external, which does not depend on the behavior of payment system counterparties. It is proved that the process of minimizing the risks of payment systems should be considered in the form of a mechanism that allows determining the main aspects of the use of financial instruments and regulating the operation of cash regulators in banking institutions involved in this process. The categorical-conceptual apparatus concerning the mechanism of minimization of risks of payment systems of banking institutions is offered. A comprehensive approach to the formative process of the mechanism of minimizing the risks of payment systems of banking institutions, which clearly regulates the relationship of all its structural elements aimed at achieving the strategic objectives of banks' operations. The elements of the mechanism of minimizing the risks of payment systems of banking institutions are determined. The environment of 
action of organizational and economic components of the mechanism of minimization of risks of payment systems of banking institutions is detailed.

В статті представлено напрями мінімізаиії ризиків платіжних систем банківських установ в контексті розвитку циифровізації економіки та впливу факторів зовнішнього середовища на функціонування суб'єктів платіжного ринку. 3 метою визначення характерних ознак загроз щздо здійснення корпоративних банківських операцій під впливом факторів зовнішнього середовища запропоновано категорію «ризик платіжних систем банківських установ». Обтрунтовано, щу непередбачувані відхилення від очікуваних результатів використання фінансових інструментів в міжбанківських системах грошових переказів, які забезпечують грошовий обіг через активно-пасивні операції, скорочують обсяг операційної діяльності банківських установ, їх розрахункові прочеси за платежами $i$ переказами учасників та користувачів послуг платіжсни систем. Доведено, поділ ризиків на специфічні $i$ індивідуальні дозволяе оцінити стан платіжної системи в двох напрямах: внутрішньої щзодо технології розрахункових операцій, які повністю залежать від діяльності учасників системи платежів, і зовнішньої, яка не залежить від поведінки контрагентів платіжної системи. Доведено, щзо процес мінімізації ризиків платіжних систем слід розглядати у формі механізму, який дозволяє визначити основні аспекти використання фінансових інструментів й регламентувати дію регуляторів грошового обігу в банківських установах, залучених до даного процесу, забезпечити належні умови високоефективного їх функціонування та сформувати оптимальну величину банківського платіжного портфелю. Запропоновано категоріально-понятійний апарат щодо механізму мінімізації ризиків платіжних систем банківських установ. Розроблено комплексний підхід до формоутворюючого процесу механізму мінімізації ризиків платіжних систем банківських установ, який чітко регламентує взаємозв'язок всіх його структурних елементів, спрямованих на досягнення стратегічних иілей операчійної діяльності банків. Визначено елементи механізму мінімізації ризиків платіжних систем банківських установ. Деталізовано середовище дї організаџійної та економічної складових механізму мінімізації ризиків платіжних систем банківських установ.

Ключові слова: платіжні системи; ризики; банківські установи; банківська система; міжбанківські перекази.

Keywords: payment systems; risks; banking institutions; banking system; interbank transfers.

Formulation of the problem. The payment system of banking institutions of Ukraine is an indicator of the state of the national economy, one of the priority areas of development of which is the modernization and improvement of financial instruments in interbank money transfer systems. Because the state of the payment market is important for a market economy, and modern paper money cannot meet all the demands of economic entities that arise during their interaction, so alternative means of payment become urgent. As a result of evolution and under the influence of digitalization and globalization, money continues to change its appearance and acquire a more perfect form - the most suitable for use in payment systems for settlements and payments. This effect affects the state of money circulation.

At the same time, the rapid and irreversible digitalization of the world has become an objective process, and its essence and consequences for the impact on the world economy are the subject of research and discussion in the scientific community. The further development of the financial sphere through the use of innovative technologies, ideas and products depends on scientific and technological progress, as one of the main driving forces of globalization. Transformations of technological innovations are gradually changing payment systems, implementing the modern needs of their users. Due to the dynamics of change, payment service entities, central banks and international organizations try to interact with each other, combining different levels of cooperation (from purely technical organization of money transfer to harmonization of legislation in the field of transfers), which is important for continuous and reliable payment systems of international and domestic importance. At the same time, their effectiveness should be based on appropriate fundamental research in the formation of an effective mechanism for minimizing the risks of payment systems and regulating financial relations in the banking sector.

Analysis of research and publications. Problems of functioning and development of payment systems were studied by such scientists as, як O. Baranovskyi [1], O. Vovchak, H. Shparhalo, T. Andreikiv [2], O. Kolodizyev, I. Pleskun 
[8], M. Campbell-Verduyn [12], J. Caldera, J. Hain, K. Sherlock [13]. Theoretical and methodological aspects of risk management are considered in the works of leading domestic and foreign scientists, including O. Berezhny [3], T. Bolhar [4], O. Hlushchenko, I. Semehen [5], V. Kovalenko [7], L. Prymostka [9], O. Utkina [11], A. Irwin, K. Choo, L. Liu [14], D. Masciandaro [15], M. Weber, T. Suzumura, A. Pareja, H. Kanezashi, T. Schardl [16]. However, the issue of forming a mechanism for minimizing the risks of payment systems in Ukraine and their development deserve special attention in the context of digitalization of the economy and globalization processes.

The aim of the study is to develop directions of minimizing the risks of payment systems of banking institutions in the context of the development of digitalization of the economy and the impact of environmental factors on the functioning of payment market participants.

Presentation of the main results and their substantiation. Banks are the main participants in the payment market; the general development of Ukraine's economy depends on their stable functioning. The payment system of the banking sector, the main function of which is to make payments, transfers and / or settlements, includes not only payment market participants, but also complex technical and technological interaction between them and the payment infrastructure, which is a set of interconnected elements and connections between them, affects each other and forms one whole [2]. The system is characterized by structure and integrity, in which certain banking processes take place. However, in modern conditions of increasing instability of national and world payment markets it is important to form the financial stability of the banking payment system of Ukraine, as the probability (threat) of losing part of banks resources, losses, loss of income or additional costs as a result of inefficient financial transactions in the payment system compared to the expected option, leads to unexpected risks [1]. However, in certain forms of active-passive transactions, the risks of payment systems are identified, which have the characteristic features of threats to corporate banking operations under the influence of environmental factors. This gives grounds to consider them as a separate concept. In view of this, under the category "risk of payment systems of banking institutions" we propose to understand the probability of deviation from the expected results of the use of financial instruments in interbank money transfer systems, which provide money circulation through active-passive operations, their organization, resulting in reduced operational activities of banking institutions, their settlement processes for payments and transfers of participants and users of payment systems or third parties through interaction between them.

Objective factors of the external environment of banks and the requirements of regulators to reduce the risk of operating activities of banking institutions necessitated the development of a mechanism to minimize the risks of payment systems, because the crisis in the payment system has called into question the ability of banks to take into account the dynamics of the operating environment, as evidenced by the results of their operation (Fig. 1-6).

The significant decrease in their level of profitability was due not so much to macro-factors as to the lack of attention to improving risk minimization methods. Therefore, the process of minimizing the risks of payment systems should be considered in the form of a mechanism that identifies the main aspects of the use of financial instruments and regulates the operation of monetary regulators in banking institutions involved in this process and ensure proper conditions for their efficient operation forming the optimal size of the bank's payment portfolio.

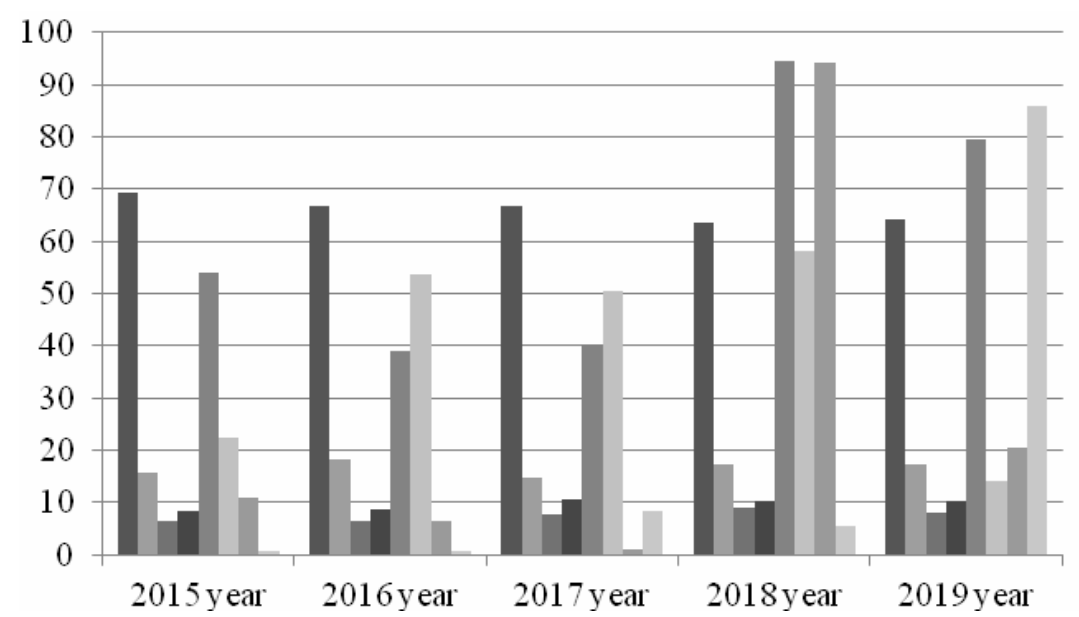

Fig. 1. The share of assets and profits by groups of banks of Ukraine in 2015-2019

\footnotetext{
Source: calculated and compiled by the authors based on data [6]
}

The share of assets of banks of group I, \%

The share of assets of banks of group II, \%

The share of assets of banks of group III, \%

The share of assets of banks of group IV, \%

The share of profitable banks of group I, \%

The share of profitable banks of group II, \%

The share of profitable banks of group III, $\%$

The share of profitable banks of group IV, \% 


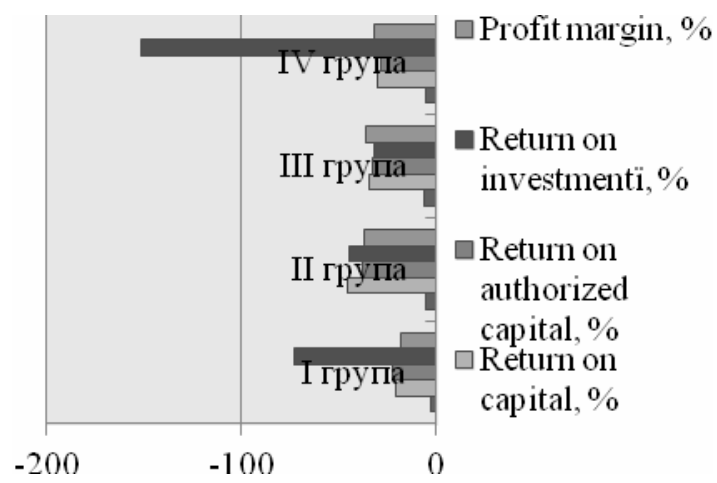

Fig. 2. The efficiency of operating activities of banking institutions of Ukraine in $\mathbf{2 0 1 5}$

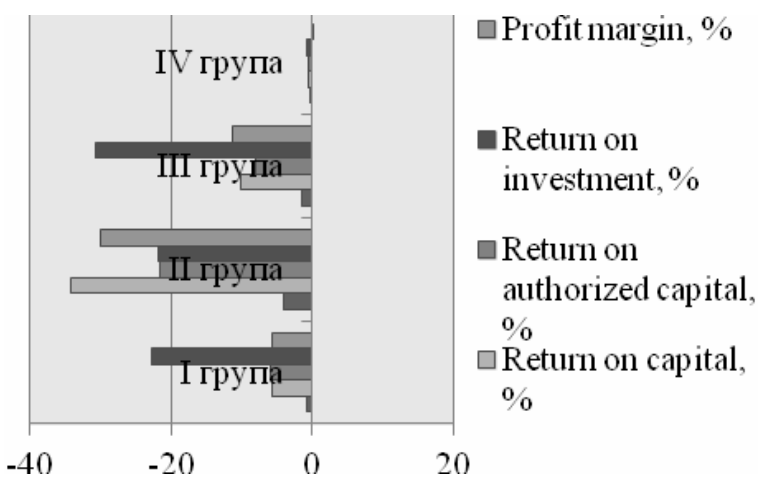

Fig. 3. The efficiency of operating activities of banking institutions of Ukraine in 2016 p.

Source: calculated and compiled by the authors based on data [6]

Thus, it should be noted that the volume of the payment portfolio of banks for settlement operations and transfers in the payment systems of Ukraine in 2019 amounted to almost $75 \%$ of the total cash flow of the banking sector. Money supply was withdrawn from the country through payment systems $3.85 \%$. The volume of payment systems formed by residents in Ukraine during this period was equal to 19.06 billion UAH, which is almost $100 \%$-th of the total money turnover in the country through banking institutions. The value of the incoming money supply to Ukraine through the banking system of transfers of non-residents (international institutions) was equal to 54.97 billion UAH.

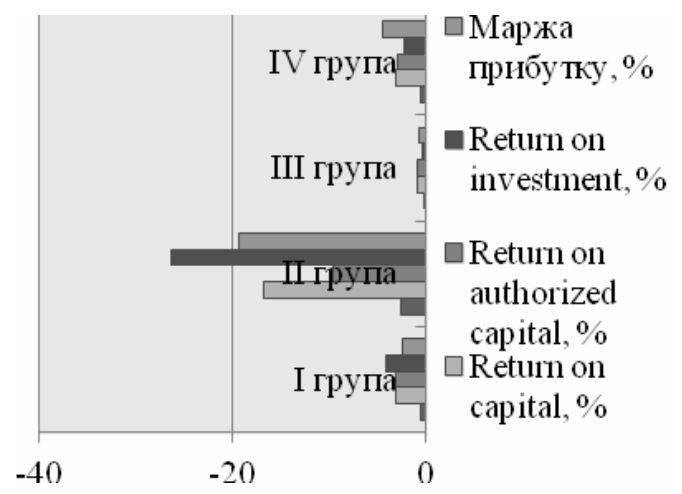

Fig. 4. The efficiency of operating activities of banking institutions of Ukraine in $2017 \mathrm{p}$.

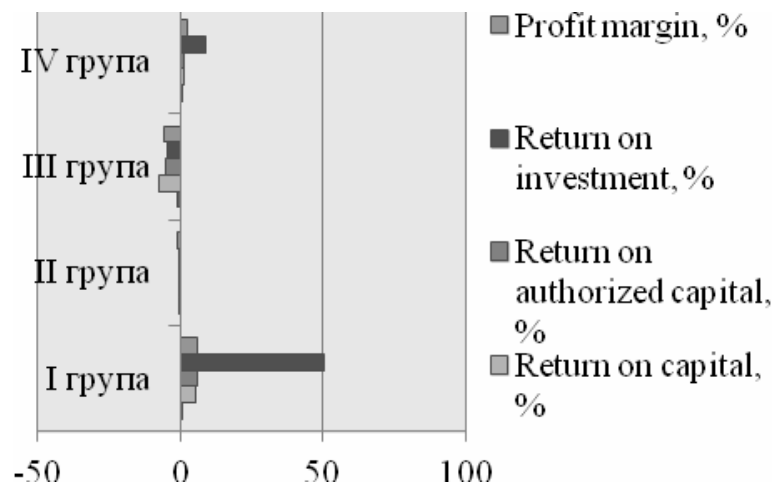

Fig. 5. The efficiency of operating activities of banking institutions of Ukraine in $2018 \mathrm{p}$. Source: calculated and compiled by the authors based on data [6]

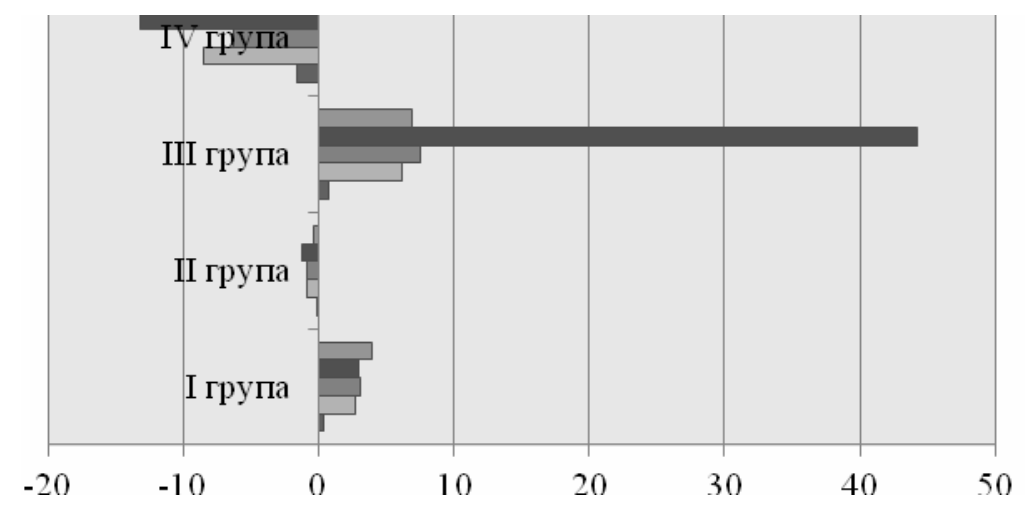

$\square$ Profit margin, \%

- Return on investment, $\%$

$\square$ Return on authorized capital, \%

$\square$ Return on capital, \%

- Return on assets, \%

Fig. 6. The efficiency of operating activities of banking institutions of Ukraine in 2019 Source: calculated and compiled by the authors based on data [6]

Outside Ukraine, the outgoing cash flow through the payment systems of residents' banking institutions amounted to 0.15 billion UAH, non-residents - 10.13 billion UAH. (Fig. 7).

In general, in the economic literature there is still no single approach to the interpretation of the mechanism of minimizing the risks of payment systems, by which we propose to understand the system of interdependent 
organizational and economic elements of remittances interacting with the objects of settlement process and payment system.

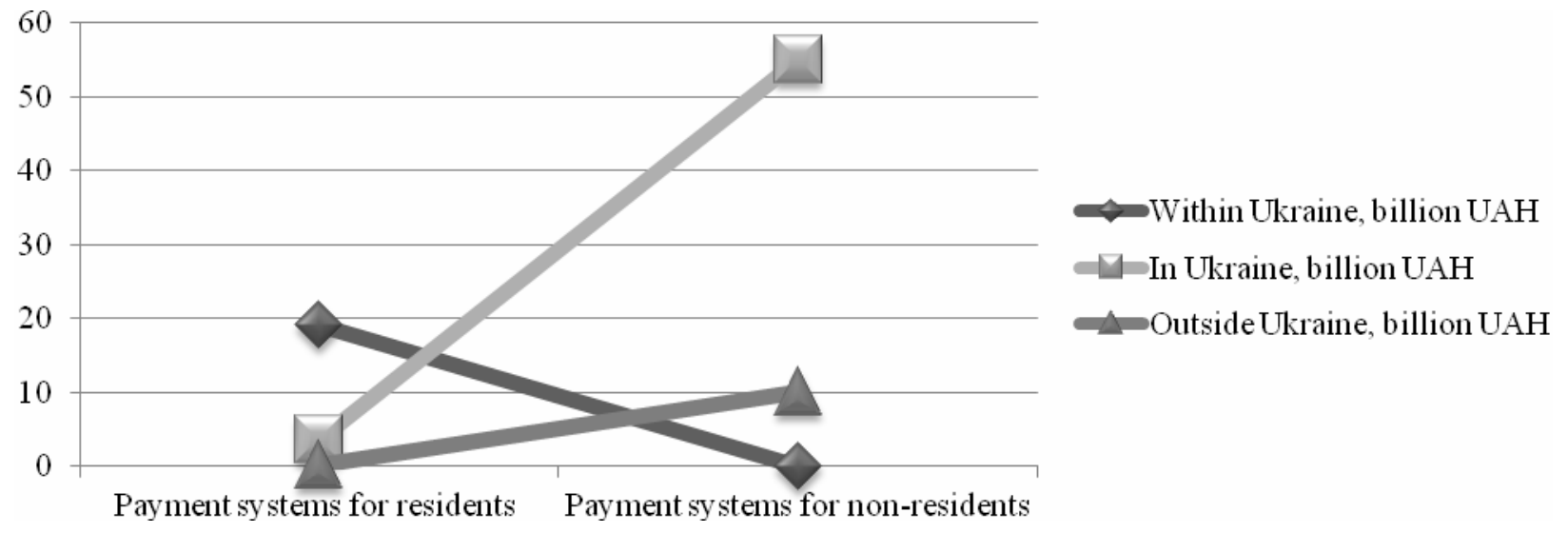

Fig. 7. Volumes of operations of payment systems (transfer systems) in Ukraine in 2019, billion UAH Source: calculated and compiled by the authors based on data [6]

Thus, it makes possible the formation of the planned level of profitability, risk and liquidity of institutions (organizations) within the relevant principles, methods, levers and cash flows in order to quickly respond and adapt its actions to changes in the external environment. Based on this interpretation, we proposed the concept of "risk minimization mechanism of payment systems of banking institutions". This is a system of methods, techniques and levers that outline the conditions and sequence of risk management in interbank money transfers, which through qualitative criteria and financial instruments allows to form optimal payment portfolio of banks, to adapt their functioning to changes in external and internal factors of the payment market, to achieve the planned level of profitability of settlement operations and efficient operations.

The target of this mechanism is the formation of favorable organizational and economic conditions for the most profitable and least risky payment activities to achieve efficient operation of banks, as well as rapid adaptation of technology and tools to minimize the risks of payment systems to changes in operating environment.

Taking into account the above aspects allowed identifying a number of elements of the mechanism for minimizing the risks of payment systems of banking institutions, which can be divided into two components. The first the macroeconomic level of the payment system of banks, which is the basic unit of the mechanism and provides the basic conditions for the implementation of all its other components, forms the basis for the formation of tools for minimizing risks at the interbank level. It includes the regulatory influence of the NBU on the payment portfolio of banks and interbank settlement operations, takes into account the strategy of monetary policy of the state, which affects the strategy of banks, including in planning their operations. The second - the microeconomic level - the operating environment of banks, in which on the basis of certain strategic areas of risk minimization the payment policy is formed. Their need is due to the need for a clear and consistent methodology for assessing the risks of banking activities, aimed at optimizing the settlement process through the formation of risk limits in the payment portfolio of banks.

In general, the analysis of the internal banking environment should focus on identifying potential opportunities for banks to ensure a quality process of minimizing the risk of payment systems, which will not only identify possible areas for improvement, but also ensure effective banking.

The organizational component of the mechanism for minimizing the risks of payment systems of the banking institution is a set of structural and functional elements that ensure interaction and coordination of individual subsystems of the bank to ensure the efficiency of active-passive payments and transfers of participants of the interaction of the settlement process and the impact of risks on it in the changing needs of users of payment system services in a dynamic operating environment. With the qualitative formation of the organizational component of the mechanism on scientifically sound approaches, through clear coherence of relations and rules of interaction of participants in the payment process will ensure effective organization of the bank to minimize risks and increase efficiency of optimization of the payment portfolio.

The economic component of the mechanism of minimizing risks of payment systems of banking institutions is a set of tools and effective actions aimed at implementing the process of minimizing risky settlement operations within interbank payment transfers of national and world payment systems formed by residents and nonresidents through the NBU EPS. This perception of the economic component of the mechanism emphasizes its focus on increasing the size of the payment portfolio in the operating activities of banking institutions. This can be achieved by improving the forecasting of the amount of risk based on a comprehensive model of risk assessment of an individual participant within the payment system of electronic payments of the NBU (NBU EPS) and optimization of the payment portfolio of banks.

The best method of assessing the economic component of the mechanism of minimizing the financial risks of payment systems is a consistent consideration of its elements, the starting point of which is the analysis of the operating environment of banking institutions with in-depth assessment of elements of the organizational component(regulation by the NBU of banks' payment policy on cash acceptance and subsequent transfer, taking into account financial risk 
macro-factors) and micro-levels (internal bank policy of optimal payment portfolio formation, sequence of stages of risk management formation to minimize the risks of payment systems).

Thus, to the economic component of the mechanism of minimizing the risks of payment systems, we include the following formative elements (technical-technological, spatial-reactionary, reaction-adaptive, control-monitoring and postoperative support), which together with active-passive operations on payments and transfers of participants of settlement process and variable needs of users of payment system services make it possible to reduce the impact of risks in the dynamic environment of banking institutions. We consider them in more detail:

- technical and technological support aimed at analyzing and improving the technology and methods of minimizing the risks of payment systems (sequence of stages, features of operational actions), which will improve the development of the card payment market and reduce the asymmetry of the information array to optimize operational actions for non-cash transactions using payment cards and reducing their risk (computer support, automation, security and data protection, etc.), which is the initial level of the process of minimizing the risks of payment systems (identification and risk assessment);

- spatial response support includes the implementation of operational actions of banking institutions in relation to previously identified risk factors and risk assessment of payment transfers between participants in the NBU electronic payment system (NBU EPS). It is a set of economic levers and organizational and legal means of influencing the NBU EPS on banking institutions in order to determine the tools to minimize the risks according to available data over time.

- control and monitoring support is one of the key elements of the mechanism, it allows to determine the effectiveness of the bank's measures, methods, tools and levers to influence risks through constant control and monitoring of their migration, payment system efficiency and optimal operational actions to reduce risk and increase profitability of settlement processes. This element also serves as a basis for reaction-adaptive support;

- postoperative support includes work with problematic payment systems that have arisen as a result of the implementation of a risky money transfer procedure. This element is aimed at optimizing the settlement process by freeing the bank's balance sheet from inefficient (risky) payment systems and increasing the liquidity of the payment portfolio.

Due to the need to improve the mechanism through the dynamism of the operating environment of banking institutions, feedback channels are provided, through which it is possible to quickly adjust the elements of the mechanism and identify critical features in their formation. To do this, we have proposed a reaction-adaptive unit, which, in our opinion, should combine the results of the mechanism, and its effective functionality (implementation) - to provide directions for optimizing payment and pricing policies of banking institutions, to determine adaptive measures for crisis management. Qualitative implementation of this element is one of the main tasks of the risk minimization mechanism of payment systems of banking institutions, because it is based on adjusting both the risk minimization system and the settlement process in accordance with changes in banks, new valuation methods or tools and innovative technologies.

Such improvement should be permanent and comprehensive, so taking into account the possibility of adapting to changes in the external environment is an integral part of an efficient banking institution that rationally uses its own resources to achieve strategic goals of operations. For the efficiency of adaptation, it is necessary to determine the time interval, namely the beginning of response to a risky event for the timely selection of appropriate measures, the effectiveness of which depends on the quality of control, i.e. verification of the application of adaptation measures (a set of methods and tools aimed at changing the object of payment systems, ensuring the normal functioning of banks in dynamic conditions), determining their validity, the need for corrections, as well as effectiveness (identifying compliance with changes in the environment of activity).

Thus, a mandatory system of operational action and regulation of payment relations should become a mandatory element of the mechanism. In view of this, preventive measures to prevent possible risks are planning and design of a payment product, setting the level of its risk based on the assessment of the solvency of participants of the NBU EPS and regular users of payment systems; control and monitoring of both specific financial risks and payment portfolio risk. In addition, banking institutions need to systematically improve methodological provisions and recommendations for assessing and minimizing the risks of payment systems, taking into account the dialectical combination of external (level of achievement of business objectives) and internal (achievement of economic performance) efficiency of the payment portfolio. These conditions determine the ability of banking institutions to ensure profitability and diversification of development through the selection and implementation of optimal strategies to achieve not only economic effect, but also adaptability and flexibility in the international payment system. Therefore, the complexity of the application of these elements and their comprehensive development forms an adaptive model of the mechanism of minimizing the risks of payment systems, aimed at optimizing the operating activities of banking institutions in a market economy.

Conclusions and suggestions. Thus, integration settlement processes have a significant impact on the functioning and development of global and national payment systems of the banking sector. The use of electronic payment systems to ensure the transfer of funds between users of the system in real time via the Internet is becoming commonplace. However, it is necessary to be aware that challenges arise in the infrastructure of the payment market, thus hindering the effective functioning of banking institutions due to the concentration of risks and threats in payment systems, which change throughout their existence. This requires the introduction of an effective tool for effective functioning of the risk minimization mechanism and the development of a methodological approach to assessing a comprehensive index of risk description, which characterizes the level of risk in the payment system. 


\section{References.}

1. Baranovskyi, O.I. (2014), Filosofiia bezpeky. T. 2: Bezpeka finansovykh instytutiv [Filosophy of security. vol.2. Security of financial institutions], UBS NBU, Kyiv, Ukraine. Kyiv, Ukraine.

2. Vovchak, O.D., Shparhalo, H.Ie., Andreikiv, T.Ia. (2008), Payment systems [Platizhni systemy], Znannia,

3. Berezhny, O. (2009), "Risks of using banks services for the legalization of illegal incomes and terrorism financing in the system of banks risks", Visnyk NBU, vol. 4, p. 3.

4. Bolhar, T. M. (2009), "Financial security of banks in conditions of market transformation of the economy in Ukraine”, PhD Thesis, Money, finance and credit, SHEI «Ukrainian academy of banking of the National Bank of Ukraine».

5. Hlushchenko, O. O. and Semehen, I.B. (2014), Antylehalizatsiynyy finansovyy monitorynh: ryzyk-oriyentovanyy pidkhid [Antilegalization financial monitoring: risk-based approach], UBS NBU, Kyiv, Ukraine.

6. Activities of money transfer systems in Ukraine (2020), National Bank of Ukraine, available at: https://bank.gov.ua/file/download?file=PS_oversayt_per_kosht_graf_2019.pdf. (Accessed 18 Aug 2020)

7. Kovalenko, V. V. (2019), "Risks of money laundering through the banking system in a digital economy", Biznesnavihator, vol. 3-2 (52), pp. 83-93.

8. Kolodizyev, O. M. and Pleskun, I. V. (2017), "Financial monitoring at banks in Ukraine: essence and definition of problems of realization in modern conditions of economic development", Upravlinnya ryzykom, vol. 3-4, pp. 189-190.

9. Prymostka, L. O. (2008), Bankivs'ki ryzyky: teoriya ta praktyka upravlinnya [Bank risks: management theory and practice], Ministerstvo osvity i nauky Ukrayiny: Derzhavnyy vyshchyy navchal'nyy zaklad «Kyyivs'kyy natsional'nyy ekonomichnyy universytet im. Vadyma Het'mana», Kyiv, Ukraine.

10. SEP. Facts and figures for (2019), National Bank of Ukraine, available at: URL: https://bank.gov.ua/news/all/sep-fakti-ta-tsifri-2019-rik. (Accessed 18 Aug 2020)

11. Utkina, O. V. (2019), "Characteristics of Money Laundering / Terrorist Financing Risk Management and Areas of Improvement”, Finansovyy prostir, vol. 4, pp. 217-220.

12. Campbell-Verduyn, M. (2018), "Bitcoin, crypto-coins, and global anti-money laundering governance", Crime, Law and Social Change, vol. 69(2), pp. 283-305.

13. Caldera, J., Hain, J. M. and Sherlock, K. (2016), "Enhanced automated anti-fraud and anti-money-laundering payment system”, U.S. Patent Application, vol. 14/846, pp. 169.

14. Irwin, A. Choo, K.-K. R. and Liu, L. (2011), "An analysis of money laundering and terrorism fnancing typologies”, Journal of Money Laundering Control, vol. 15, pp. 85-111.

15. Masciandaro, D. (2017), Global Financial Crime: Terrorism, Money Laundering and Offshore Centres, Taylor \& Francis, London, UK.

16. Weber, M. Chen, J. Suzumura, T. Pareja, A. Ma, T. Kanezashi, H. and Schardl, T. B. (2018), "Scalable graph learning for anti-money laundering: A first look", arxiv preprint, available at: https://arxiv.org/abs/1812.00076. (Accessed 18 Aug 2020)

\section{Література.}

1. Барановський О.І. Філософія безпеки: [монографія]: у 2-х т. Т. 2: Безпека фінансових інститутів. К.: УБС НБУ, 2014. 715 с. $2008,341 \mathrm{c}$

2. Вовчак О.Д., Шпаргало Г.С., Андрейків Т.Я. Платіжні системи: навчальний посібник. Київ: Знання,

3. Бережний О. Ризики використання послуг банків для легалізації доходів, отриманих злочинним шляхом, або фінансування тероризму в системі банківських ризиків. Вісник НБУ. 2009. № 4, с. 3.

4. Болгар Т. М. Фінансова безпека банків в умовах ринкової трансформації економіки України: автореферат дис. канд. екон. наук: Державний вищий навчальний заклад «Українська академія банківської справи Національного банку України». 2009. 21 с.

5. Глущенко О.О., Семеген І.Б. Антилегалізаційний фінансовий моніторинг: ризик-орієнтований підхід. К.: УБС НБУ. 2014. 386 с.

6. Діяльність в Україні систем переказу коштів. 2020. Національний банк України: вебсайт. URL: https://bank.gov.ua/file/download?file=PS_oversayt_per_kosht_graf_2019.pdf.

7. Коваленко В.В. Ризики відмивання грошей через банківську систему в умовах розвитку цифрової економіки. Бізнес-навігатор. 2019. Вип. 3-2 (52). С. 83-93.

8. Колодізєв О.М., Плескун І.В. Фінансовий моніторинг у банках України: сутність і визначення проблем реалізації в сучасних умовах розвитку економіки. Управління ризиком. 2017. №3-4, С.189-190.

9. Примостка Л.О. Банківські ризики: теорія та практика управління: монографія: Міністерство освіти і науки України. Державний вищий навчальний заклад «Київський національний економічний університет ім. Вадима Гетьмана». КНЕУ, 2008. 129 с.

10. СЕП. Факти та цифри 2019 року. Національний банк України: вебсайт. URL: https://bank.gov.ua/news/all/sep-fakti-ta-tsifri-2019-rik.

11. Уткіна О.В. Характеристика управління банківським ризиком відмивання коштів/фінансування тероризму та напрями його вдосконалення: Фінансовий простір. 2019. № 4, С. 217-220.

12. Campbell-Verduyn, M. Bitcoin, crypto-coins, and global anti-money laundering governance. Crime, Law and Social Change. 2018. 69(2). P. 283-305. 
13. Caldera, J., Hain, J. M., \& Sherlock, K. Enhanced automated anti-fraud and anti-money-laundering payment system U.S. Patent Application No. 14/846,169. 2016.

14. Irwin, Angela \& Choo, Kim-Kwang Raymond \& Liu, Lin. An analysis of money laundering and terrorism fnancing typologies. Journal of Money Laundering Control. 2011. 15. P. 85-111.

15. Masciandaro, Donato. Global Financial Crime: Terrorism, Money Laundering and Offshore Centres. Taylor \& Francis. 2017.

16. Weber, M., Chen, J., Suzumura, T., Pareja, A., Ma, T., Kanezashi, H., \& Schardl, T. B. Scalable graph learning for anti-money laundering: A first look. arXiv preprint. 2018. Retrieved from: https://arxiv.org/abs/1812.00076

Стаття надійшла до редакиії 14.01.2021 p. 